\title{
Quantitative Chemical Analysis of Slag Ash of Novocherkassk State District Power Plant
}

\section{TATYANA GERMANOVNA KOROTKOVA*, SVETLANA JUREVNA KSANDOPULO, SVYATOSLAV ANDREEVICH BUSHUMOV, SVETLANA DMITRIEVNA BURLAKA and YULIYA VASILEVNA SAY}

\author{
Kuban State Technological University, 350002 Russian Federation, \\ Krasnodar, Moskovskaya Street 2. \\ ${ }^{\star}$ Corresponding author E-mail: t.g.korotkova@mail.ru \\ http://dx.doi.org/10.13005/ojc/330121
}

(Received: December 17, 2016; Accepted: January 22, 2017)

\begin{abstract}
Quantitative chemical composition of ash and slag mix generated upon combustion of Donetsk culm is determined. It is established that ash and slag mix of Novocherkassk state district power plant (SDPP) (Rostov region, Russia) after coal combustion has the following composition: iron $-2.3 \%$; mineral constituents $-75.8 \%$; calcium oxide $-20.4 \%$; aluminum oxide $-0.0118 \%$; water $-1.3022 \%$; manganese oxide $-0.18 \%$; copper oxide $-0.0043 \%$; plumbum $-0.0017 \%$; it is qualified as hazard class IV for environment. Cadmium, mercury, arsenic, selenium, antimony, bismuth are contained in trace amounts $<0.1 \mathrm{mg} / \mathrm{kg}$. In order to reduce dust emissions the cleaning stage I of gas scrubbing facility is equipped with group cyclone comprised of four cyclone units. Medium and coarse particles under the action of centrifugal force are deposited in the cyclone. This promoted decrease in dust load on bag filters, the cleaning stage II. Qualitative chemical composition of ash captured by group cyclone and that of ash captured by bag filter are determined. Cadmium, copper, plumbum, zinc, iron, manganese, and calcium are contained in coarse and fine particles captured by group cyclone and bag filter. Aluminum referred to light metals is completely captured by cyclone. The ash dust in its bulk is of dark gray color. The ash captured by cyclone contains coarse particles of black color and the ash captured bag filter contains fine particles of light colors (gray-yellow color producing silky gloss). This is characteristic for ash dust after combustion of Donetsk culm. The main component of the ash is silicon dioxide, its content in the ash captured by filter reaches $91 \%$. These fine particles create light tone of this ash.
\end{abstract}

Keywords: Fly Ash, Slag ash, Quantitative chemical analysis, Thermal power plant.

\section{INTRODUCTION}

Novocherkassk SDPP is located in Donskoi housing complex, Novocherkassk, Rostov region of Southern Federal District (Russia). Slag ash are generated after combustion of solid fuel in boilers of Novocherkassk SDPP. Dry ash after combustion is deposited in electric filter. Ash particles with the size 
from 3-5 $\mu \mathrm{m}$ to $100-150 \mu \mathrm{m}$ is referred to as fly ash. Ash particles with the size in excess of $150 \mu \mathrm{m}(0.15$ $\mathrm{mm}$ ) is referred to as ash and slag wastes (ASW) or coal slag. Using compressors and pneumatic pumps the ash is conveyed via pipelines to silos. As consequence of pumping the ash particles of various fineness travel with air, a portion of these particles is carried away to transport network. Thus, prior to emission into atmosphere contaminated air should be cleaned. Group cyclone and bag filter are used as mechanical ash collectors.

This article discusses data on quantitative chemical analysis of ash and slag mix of Novocherkassk SDPP, selected before the group cyclone, from group cyclone and from bag filter. Wastes are generated as a consequence of combined removal of fuel slag and ash. Donetsk culm are used as solid fuel. Interim storage (accumulation) of the wastes is performed in ash and slag dump located on the premises of the company.

\section{Related works}

Main technogenic wastes of thermal power plants and SDPP are slag ashes and flue gases. Upon coal combustion in boilers organic portion is burned generating flue gases. Inorganic portion is transformed into slag ash. Fly ash is carried out by flue gases and captured in ash collectors. Ash and slag are unburned residue of solid fuel stored in ash and slag dump. Depending on the coal type and combustion method fly ash and slag ash are characterized by various physicochemical properties and particle size distribution.

\section{Slag and ash are a real challenge for many countries. Let us consider this issue more deeply}

In India with its high density of population thermal power plants generate huge amounts of ûy ash, thus affecting environment and water resources. Approximately 260 million tons of cola are consumed annually by 82 thermal power plant in India, which results in generation of 108 million tons of fly ash annually. Fly ash occupies large surface area and is hazardous for environment. Fly ash pollutes air and water, it creates breathing problems. In addition, while depositing on leaves and grain crops in agricultural regions in vicinity of power plants, it reduces harvest. Chemical composition of ash and slag was analyzed by X-Ray fluorescence technique, which is one of the most widely applied method of quantitative analysis (Table 1). It is established that the main components are $\mathrm{Si}, \mathrm{Al}$ and $\mathrm{Fe}$. In slag ash $\mathrm{SiO}_{2}$ content is $77.4 \mathrm{wt} \%$, in fly ash $\mathrm{Al}_{2} \mathrm{O}_{3}$ content is $32.8 \mathrm{wt} \%$. The researchers in [1] arrived to conclusion about reasonability of development of extraction technology of silicon and aluminum, using slag and ash as secondary source for recovery of valuable elements.

Similar issue of impact of Indian coal, nuclear and hydro power plants on environment and human life was discussed in [2]. Many countries of the world aim at increase in electricity production by erection of new power plants. Coal is the only natural resource and fossil fuel abundantly available in India. Coal combustion by thermal power plants results mainly in emission of carbon dioxide $\left(\mathrm{CO}_{2}\right)$, sulfur oxides $\left(\mathrm{SO}_{x}\right)$, nitrogen oxides $\left(\mathrm{NO}_{x}\right)$; $\mathrm{CFC}$ trace gases, inorganic macroparticles, such as flue ash and suspended particulate matter (SPM). $\mathrm{CO}_{2}, \mathrm{NO}_{x}$ and CFCs are greenhouse gases. High ash content in Indian coals and inefficient combustion technologies result in emission of particulate contaminants and gases responsible for greenhouse effect. Table 1 summarizes chemical composition of fly ash with high content of $\mathrm{Fe}_{2} \mathrm{O}_{3}$ (Iron oxide): $63 \%$.

Luohuang power plant, one of the largest thermal power plants in south-west of Chine, consumes approximately six million tons of coals per year with annual generation of fly ash up to two million tons [3]. It is highlighted that coal consumption and, hence, emission of coal fly ash, constantly increases, negatively effecting on environment and human life. Interaction of dust with high amount of silicon dioxide results in development of the most frequent and severe form of pneumoconiosis: silicosis. Coal dust also induces lung cancer. Fluorosis is the disease caused by prolonged intake of fluorine. Loss on ignition (LOI, \%) and content of major elements (\%) in Luohuang ûy ash are summarized in Table 2.

Data analysis (Table 2) demonstrates that content of $\mathrm{SiO}_{2}$ and $\mathrm{Al}_{2} \mathrm{O}_{3}$ in Luohuang fly ash (China) is less than that in Haryana fly ash (India) (Table 1), but is high, nevertheless. 
Ash composition of lignite (China) was analyzed in ${ }^{4}$ (Table 3). Content of $\mathrm{SiO}_{2}$ (59.04 wt $\%), \mathrm{Al}_{2} \mathrm{O}_{3}\left(18.02\right.$ wt \%), $\mathrm{Fe}_{2} \mathrm{O}_{3}(5.83$ wt \%) and $\mathrm{CaO}$ $(5.80 \mathrm{wt} \%)$ is high.

Ash and slag in Romania also contain high amount of silica $\mathrm{SiO}_{2}$ and aluminium oxides $\mathrm{Al}_{2} \mathrm{O}_{3}{ }_{3}$. It is recommended to use ash and slag for production of building materials. Titanium dioxide $\mathrm{TiO}_{2}$ is contained in all considered samples but due to its minor content the authors believe that its extraction is inefficient.

The issue of disposal and reprocessing of slag ash wastes as well as researches in the field of development of new technologies attract attention in many countries of the world.

Ordinary Portland cement (OPC) was studied with new binder from locally available slag and fly ash (Malaysia) ${ }^{5}$. Portland cement is widely applied everywhere. It is a hydraulic binder, obtained by combined milling of cement clinker, gypsum and additives with predominant content of calcium silicate (70-80\%). Combination of $60 \%$ slag and $40 \%$ fly ash was used as new binder. The use of slag in concrete increased its strength and decreased porosity. On the basis of chemical analysis it was established that slag and flue ash contain high amount of silicon dioxide and sufficient amount of basic oxides (Table 4). Around the world the fly ash generation rate is about 900 million tons per year. Fly ash and slag are generally disposed to dumps, causing great harm to environment, polluting ground and water. According to preliminary tests of consistency, setting time, and flow of binders the researchers ${ }^{5}$ concluded that at availability of chemical activator slag and flue ash can be used jointly as an alternative to OPC. The sodium hydroxide $(5 \% \mathrm{NaOH})$ and calcium hydroxide $\left(5 \% \mathrm{Ca}(\mathrm{OH})_{2}\right)$ flakes were used as a chemical activator.

Physicochemical properties of slag and ash wastes of Yurga thermoelectric plant were analyzed in [6] (Yurga, Kemerovo region, Russia). Chemical composition of slag and ash wastes was determined in samples from electric precipitator and slag ash dump. Chemical composition (Table 5) was obtained using X-ray fluorescent spectrometer. The main components in ash are silicon and aluminum oxides. In order to reveal additional possibilities of application of slag and ash wastes the major classification principles were determined: acidity modulus (electric precipitator -2.9; slag and ash dump -4.7) and basicity modulus (electric precipitator - 0.2; slag and ash dump -0.16), silicate modulus (electric precipitator - 1.7; slag and ash dump - 1.9), and quality coefficient (electric precipitator - 0.7; slag and ash dump -0.54). It was established that Yurga thermoelectric plant slag and ash wastes are referred to acid ashes. Acid ashes are characterized by unstable chemical composition, low content of free calcium oxide and high content of silicon oxide. According to the results of particle size analysis in the study ash the sizes of $60 \%$ of the particles in the considered ash are from $10 \mu \mathrm{m}$ to 70 $\mu \mathrm{m}$. The material is very fine grained. The use of slag and ash wastes in various fields of building industry would decrease the use of natural resources.

Possibility of application of slag and ash wastes of Khavarovsk thermoelectric plant-3 (Khabarovsk, Far East, Russia) as a secondary source was analyzed in ${ }^{7}$. Ash dump No. 1 is located in the Village of Fedorovka, Khabarovsk region; it was commissioned in 1985. Khabarovsk thermoelectric plant-3 operates mainly with Neryungri black coal, generation of slag and ash is about 300 thousand tpy. Ash and slag are disposed to dump by means of conveying in the form of water slurry. The major component of the considered slag and ash wastes is slag of black, gray and sometimes whitish-gray colors, with porous, pumiceous, sponge and dense structure in the form of fragments with the sizes of $0.01 \mathrm{~mm}-3.00 \mathrm{~mm}$. Silicate analysis of oxides revealed that the considered slag and ash wastes are characterized by high content of silicon and aluminum oxides and low content of calcium and magnesium oxides (Table 6). Classification properties of the material are determined: basicity modulus (hydraulic modulus) - BM; silicate (silica) modulus - SM; quality coefficient (hydraulic activity) $-\mathrm{Q}$. The basicity modulus is the ratio of content of basic oxides to that of acid oxides. The basicity modulus was $0.06(\mathrm{BM}<1)$, hence, these slag and ash wastes are acid and can be used as hydraulic additive. Silicate modulus is the ratio of content of silicon oxide reacting with other oxides to cumulative content of aluminum and iron oxides. Silicate modulus was 3.19 . Hydraulic activity was 0.27 . Therefore, 
analysis of chemical composition, physicochemical properties, and hydraulic (chemical) activity of ash and slag of Khabarovsk thermoelectric plant-3 revealed that these wastes are the most efficient as technogenic soils and in road construction, in production of ash-concrete and slag-ash silicate building materials (without additional use of natural materials in the mixes).

Comprehensive analysis of chemical and phase composition, physicomechanical properties and hydraulic (chemical) activity of ash and slag from
Barnaul thermoelectric plant-38 (Barnaul, Altai region, south of Western Siberia, Russia) demonstrated that one of the most efficient filed of their application is production of non-autoclaved ash-concrete and slag ash silicate building materials (without addition of natural materials). This would require for dry removal and storage of slag and ash to provide their subsequent utilization. Barnaul thermoelectric plant-3 operates on Kansk-Achinsk coal with low ash content, hence, generation of slag and ash is 120 thousand tpy. Ash and slag are disposed to dump by transportation in form of water slurry. Existence

Table 1: Chemical composition of fly ash and slag ash (India)

\begin{tabular}{|c|c|c|c|}
\hline \multirow[t]{3}{*}{ Component } & \multicolumn{3}{|c|}{ Wt \% } \\
\hline & \multicolumn{2}{|c|}{ Fly ash } & \multirow[t]{2}{*}{ Slag ash [1] } \\
\hline & $\begin{array}{l}\text { Haryana thermal } \\
\text { power plant [1] }\end{array}$ & $\begin{array}{c}\text { Chemical } \\
\text { Composition of } \\
\text { Fly Ash, \% [2] }\end{array}$ & \\
\hline $\mathrm{Na}_{2} \mathrm{O}$ & - & 0.28 & 2.02 \\
\hline $\mathrm{MgO}$ & 0.343 & - & 1.70 \\
\hline $\mathrm{Al}_{2} \mathrm{O}_{3}$ & 32.8 & 26 & 9.97 \\
\hline $\mathrm{SiO}_{2}$ & 56.1 & 62 & 77.4 \\
\hline $\mathrm{P}_{2} \mathrm{O}_{5}$ & 0.562 & 0.40 & 0.125 \\
\hline $\mathrm{SO}_{3}$ & 0.387 & - & 0.169 \\
\hline $\mathrm{Cl}$ & 0.0371 & - & 0.0976 \\
\hline $\mathrm{K}_{2} \mathrm{O}$ & 1.84 & 1.28 & 2.19 \\
\hline $\mathrm{CaO}$ & 1.10 & 1.13 & 1.62 \\
\hline $\mathrm{TiO}_{2}$ & 2.49 & 1.8 & 0.494 \\
\hline $\mathrm{Fe}_{2} \mathrm{O}_{3}$ & 4.30 & 63 & 4.22 \\
\hline $\mathrm{SrO}^{\circ}$ & 0.0378 & - & - \\
\hline $\mathrm{ZrO}_{2}$ & - & - & 0.0357 \\
\hline $\mathrm{SO}_{4}^{2}$ & - & 0.36 & - \\
\hline
\end{tabular}

Table 2: Loss on ignition (LOI, \%) and the concentrations of major elements (\%) in the Luohuang ûy ash

\begin{tabular}{cccccccccccc}
\hline LOI & $\mathrm{Na}_{2} \mathrm{O}$ & $\mathrm{MgO}$ & $\mathrm{Al}_{2} \mathrm{O}_{3}$ & $\mathrm{SiO}_{2}$ & $\mathrm{P}_{2} \mathrm{O}_{5}$ & $\mathrm{SO}_{3}$ & $\mathrm{~K}_{2} \mathrm{O}$ & $\mathrm{CaO}$ & $\mathrm{TiO}_{2}$ & $\mathrm{MnO}$ & $\mathrm{Fe}_{2} \mathrm{O}_{3}$ \\
\hline 4.01 & 0.77 & 1.21 & 21.59 & 48.27 & 0.13 & 0.78 & 1.21 & 5.72 & 1.78 & 0.09 & 14.09 \\
\hline
\end{tabular}

Table 3: Ash composition of lignite, wt \%

\begin{tabular}{ccccccccccc}
\hline $\mathrm{Na}_{2} \mathrm{O}$ & $\mathrm{MgO}$ & $\mathrm{Al}_{2} \mathrm{O}_{3}$ & $\mathrm{SiO}_{2}$ & $\mathrm{P}_{2} \mathrm{O}_{5}$ & $\mathrm{SO}_{3}$ & $\mathrm{~K}_{2} \mathrm{O}$ & $\mathrm{CaO}$ & $\mathrm{TiO}_{2}$ & $\mathrm{MnO}_{2}$ & $\mathrm{Fe}_{2} \mathrm{O}_{3}$ \\
\hline 1.26 & 2.71 & 18.02 & 59.04 & 0.2 & 2.5 & 2.74 & 5.8 & 0.93 & 1.26 & 5.83 \\
\hline
\end{tabular}


of hardly hydrated particles of free calcium oxide in Kansk-Achinsk coals prevents their wide application for production of building materials. Upon contact with water free calcium oxide is hydrated being accompanied with increase in volume of generated slaked lime. Building materials and products with such ash are deformed and destroyed with time. Semi-dry method of removal of high calcium slag and ash is proposed, including pneumatic collection of ash and dewatering of slag, damping of ash up to $18 \%-25 \%$ (thus providing dedusting upon loading, conveyance and unloading), transportation of ash and dewatered slag to dump by haulers, leveling and compression of unloaded slag and ash by bulldozers and loaded. Disposed ía îôàè slag and ash are consolidated in 8-24 hours with generation of monolith ash array. After complete consolidation
(28 days) their properties of slag and ash are as follows: density $-1.85-1.95 \mathrm{t} / \mathrm{m}^{3}$, strength up to 7 $\mathrm{MPa}$, coefficient of filtration - at least $10 \mathrm{~cm} / \mathrm{s}$. The use of effluent waters for consolidation of ash in combination with special plasticizers increases the strength of ash stone up to 9-10 MPa and decrease water permeability to $10^{-10} \mathrm{~cm} / \mathrm{s}$. Analysis of disposed ash array (monolith) demonstrated that pollution of natural waters with harmful substances from the dump as well as dusting are actually eliminated.

The aspects of development of slag alkaline binders on the basis of fuel slag and ash from thermoelectric plant-2 (Izhevsk, Udmurtia, Russia) and their stability under conditions of sulfate corrosion have been discussed elsewhere ${ }^{9}$. The main component of the binder is

Table 4: Chemical properties of materials (wt \%)

\begin{tabular}{lccccccccccc}
\hline Material & $\mathrm{SiO}_{2}$ & $\mathrm{Al}_{2} \mathbf{O}_{3}$ & $\mathrm{Fe}_{2} \mathbf{O}^{3}$ & $\mathbf{C a O}$ & $\mathbf{M g O}$ & $\mathbf{S O}_{3}$ & $\mathrm{Na}_{2} \mathbf{O}$ & $\mathbf{K}_{2} \mathbf{O}$ & $\mathrm{TiO}_{2}$ & $\mathbf{M n O}$ & LOI \\
\hline Slag & 33.05 & 16.36 & 0.53 & 45.0 & 6.41 & 1.21 & 0.13 & 0.42 & - & - & 3.05 \\
Fly ash & 48.67 & 14.31 & 3.51 & 1.03 & 0.39 & 0.14 & 0.21 & 0.79 & 1.13 & 0.02 & 6.26 \\
OPC & 20.99 & 4.60 & 4.44 & 67.17 & 2.53 & 2.98 & 0.03 & 0.16 & - & - & 1.3
\end{tabular}

Table 5: Chemical composition of Yurga thermoelectric plant ash, \%

\begin{tabular}{lcccccccccccc}
\hline Element & $\mathrm{SiO}_{2}$ & $\mathrm{CaO}$ & $\mathrm{Al}_{2} \mathbf{O}_{3}$ & $\mathrm{MgO}$ & $\mathrm{MnO}$ & $\mathrm{Fe}_{2} \mathbf{O}_{3}$ & $\mathrm{FeO}$ & $\mathbf{K}_{2} \mathbf{O}$ & $\mathrm{TiO}_{2}$ & $\mathbf{S O}_{3}$ & $\mathrm{BaO}_{2}$ & $\mathbf{P}_{2} \mathbf{O}_{5}$ \\
\hline Ash dump & 55.7 & 6.8 & 21.83 & 1.95 & 0.09 & 7.44 & 6.69 & 3.53 & 1.11 & 0.72 & 0.44 & 0.38 \\
Electric filter & 50.4 & 13.96 & 20.52 & 1.55 & 0.1 & 8.55 & 7.69 & 1.35 & 0.97 & 0.87 & 0.5 & 1.08 \\
\hline
\end{tabular}

Table 6: Composition of ash and slag wastes

\begin{tabular}{lcccccccccc}
\hline Element & $\mathrm{SiO}_{2}$ & $\mathrm{Al}_{2} \mathrm{O}_{3}$ & $\mathrm{Fe}_{2} \mathrm{O}_{3}$ & $\mathrm{P}_{2} \mathrm{O}_{5}$ & $\mathrm{MnO}$ & $\mathrm{MgO}$ & $\mathrm{K}_{2} \mathrm{O}$ & $\mathrm{Na}_{2} \mathrm{O}$ & $\mathrm{TiO}_{2}$ & $\mathrm{CaO}$ \\
\hline Average content, \% & 71.58 & 16.21 & 6.19 & 0.13 & 0.07 & 0.76 & 1.22 & 0.83 & 0.56 & 2.44 \\
\hline
\end{tabular}

Table 7: Chemical composition of ash and slag from thermoelectric plant-2, Izhevsk

\begin{tabular}{lccccccc}
\hline Material & \multicolumn{8}{c}{ Oxide content, \% } \\
& $\mathrm{SiO}_{2}$ & $\mathrm{Al}_{2} \mathbf{O}_{3}$ & $\mathrm{Fe}_{2} \mathbf{O}_{3}$ & $\mathbf{C a O}$ & $\mathbf{M g O}$ & $\mathbf{K}_{2} \mathbf{O}$ & $\mathbf{N a}_{2} \mathbf{O}$ \\
\hline Ash & 51.66 & 19.54 & 6.99 & 3.00 & 0.81 & 0.54 & 0.12 \\
Slag & 60.4 & 19.02 & 6.38 & 2.63 & 0.61 & 0.54 & 0.13 \\
\hline
\end{tabular}


milled fuel slag. Sodium liquid glass was used as alkaline components. Chemical composition of ash and slag was determined by $\mathrm{X}$-ray phase analysis and summarized in Table 7.

Three compositions were developed for the investigations (Table 8) with liquid glass content of $15 \%, 20 \%$, and $25 \%$, respectively. After setting the samples, cubes with the size of $20 \mathrm{~mm}$, were stored one day in air-humid conditions, then steamed in $2+4+2$ hours at $90^{\circ}+5^{\circ} \tilde{\mathrm{N}}$. Finished samples were placed into aggressive medium ( $1 \mathrm{~N} \mathrm{Na}_{2} \mathrm{SO}_{4}$ solution). Reference samples were stored in air-humid and

Table 8: Studied composition

\begin{tabular}{lcccc}
\hline \multicolumn{4}{c}{ Content, \% (by weight of the slag and ash) } \\
Slag & Ash & Liquid glass & NaOH & Water \\
\hline 60 & 40 & 15 & 10 & 8 \\
60 & 40 & 20 & 10 & 4 \\
60 & 40 & 25 & 10 & - \\
\hline
\end{tabular}

aquatic mediums. In the course of tests the samples were regularly titrated and visually examined, weighed and photographed. Fine cracks were revealed upon examination, destruction of edges was not observed. Physicochemical studies (X-ray phase, differential thermal, electron microscopy and IR spectral analyses) were performed before and after tests in aggressive medium, thus enabling detection of shape and dimensions of new formations, their identification. The obtained data evidence high sulfate resistance of the developed compositions.

Modification of slag and ash wastes of thermal power plants by milling for their application upon production of ceramic brick was proposed $\mathrm{in}^{10}$. The considered raw materials consisted of ash after combustion of black colas at SDPP-2, Tomsk and clay of Supreme field in Tomsk region, Russia. Chemical composition is summarized in Table 9. Analysis of Table 9 demonstrates that the aluminum oxide content of $12.1 \%$ in the clay characterizes it as acid product $\left(\mathrm{Al}_{2} \mathrm{O}_{3}<14 \%\right)$. $\mathrm{CaO}$ and $\mathrm{MgO}$ exist in the form of carbonate compounds.

Table 9: Chemical composition of raw stock

\begin{tabular}{lcccccccc}
\hline \multirow{2}{*}{ Name } & \multicolumn{7}{c}{ Oxide content, wt \% } \\
& LOI & $\mathrm{SiO}_{2}$ & $\mathrm{Al}_{2} \mathrm{O}_{3}$ & $\mathrm{Fe}_{2} \mathbf{O}_{3}$ & $\mathbf{C a O}$ & $\mathbf{M g O}$ & \multirow{2}{*}{$\mathbf{R}_{\mathbf{2}} \mathrm{O}$} & $\mathrm{TiO}_{2}$ \\
\hline Clay & 5.92 & 64.8 & 12.1 & 4.53 & 5.90 & 3.08 & 2.97 & 0.70 \\
Ash & 4.45 & 61.8 & 22.4 & 3.95 & 3.00 & 1.81 & 1.34 & 1.25 \\
\hline
\end{tabular}

Table 10: Chemical composition of FGS and DASM

\begin{tabular}{lccccccccccc}
\hline Material & & \multicolumn{8}{c}{ Oxide content, wt \% } & & \\
& $\mathrm{LOI}$ & $\mathrm{SiO}_{2}$ & $\mathrm{Al}_{2} \mathrm{O}_{3}$ & $\mathrm{Fe}_{2} \mathrm{O}_{3}$ & $\mathrm{CaO}$ & $\mathrm{MgO}$ & $\mathrm{SO}_{3}$ & $\mathrm{~K}_{2} \mathrm{O}$ & $\mathrm{Na}_{2} \mathrm{O}$ & $\mathrm{TiO}_{2}$ & $\mathrm{MnO}$ \\
\hline FGS & 0.6 & 37.5 & 13.88 & 1.52 & 32.75 & 7.98 & 0.88 & - & - & 4.33 & 0.56 \\
DASM & 6.1 & 48.8 & 26.70 & 5.83 & 4.80 & 3.92 & 0.32 & 0.98 & 1.06 & - & - \\
\hline
\end{tabular}

Table 11: Properties of wastes (ash and slag mix, Novocherkassk SDPP, Russia)

\begin{tabular}{ll}
\hline Description & Property \\
\hline $\begin{array}{l}\text { Code according to Federal } \\
\text { Classificatory Catalogue of Wastes } \\
\begin{array}{l}\text { Description of wastes } \\
\text { Aggregate state }\end{array}\end{array}$ & $\begin{array}{l}\text { ash and slag mix after coal combustion, low hazard } \\
\text { solid (mix of solid forms) }\end{array}$ \\
\hline
\end{tabular}


Quantitative combination of aluminum oxide, which characterizes fire resistance of the raw stock, and fusing agents - oxides of magnesium, calcium, and iron - characterizes the raw material as low melting. Loss on ignition below $5 \%$ evidences low content of residual fuel, which minimizes shrinkage of products upon roasting. Optimum modes of milling in ball mill were determined on laboratory scale. The researchers ${ }^{10}$ established that the milling time should not be higher than 12 hours, since upon further milling the particle size distribution actually does not vary.

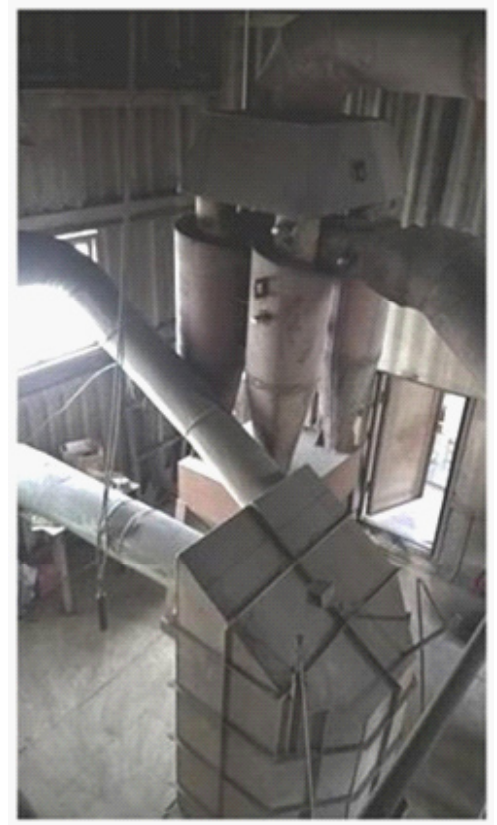

Fig. 1: Group cyclone TsN-15-500-4, Wholesale generating company OGK-2, SDPP; top view: cyclone (above), silos (below)
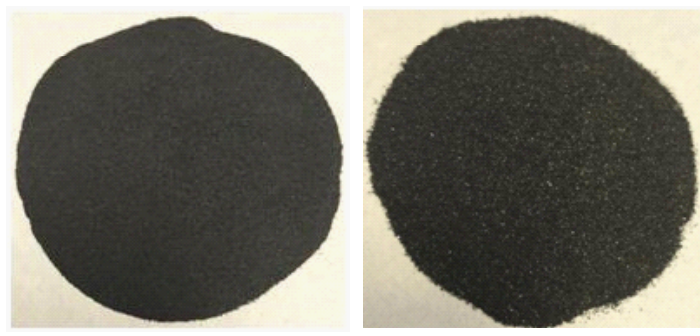

Recipe of composite cement ${ }^{11}$ was developed with mineral additive in the form of blast furnace granulated slag (FGS) and dumped ash and slag mix (DASM) from thermal power plant, its physicochemical properties satisfy the requirements of Russian standard GOST 31108-2003 General structural Portland clinker cements. Specifications. The composite cement is a hydraulic binder obtained by combined milling of Portland clinker cements, gypsum stone and composite additive composed of at least two mineral components. Chemical composition of the initial materials is summarized in Table 10.

Thus, it is obvious that generation of technogenic formations, among which slag and ash are on leading positions, is an urgent global issue. These wastes are generated at power plants upon combustion of solid fuels, accumulated in dumps, occupying large plot of lands and causing environmental damage. Therefore, the use of slag and ash mixes for production of various products will reduce environmental load and decrease expenditures for their disposal.

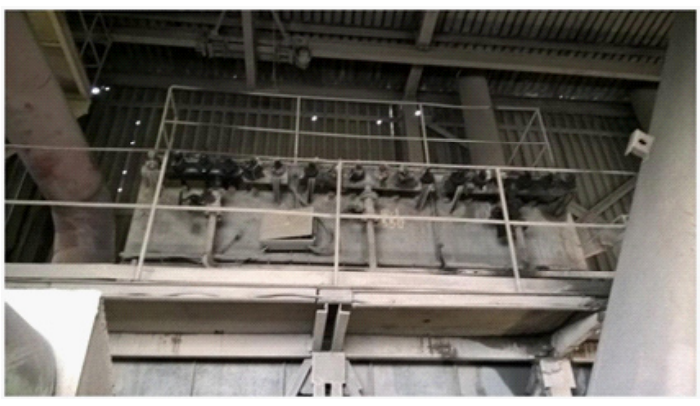

Fig. 2: Bag filter FRKI-90K-P3-2-2 (upper part), OGK-2, Novocherkassk SDPP
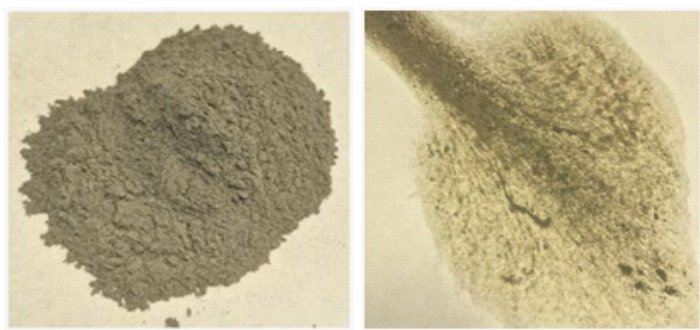

Fig. 3: ppearance of ash and slag mix of Novocherkassk SDPP 


\section{EXPERIMENTAL}

Quantitative composition of slag ash wastes in this work was determined in accordance with approved and valid in RF procedures: PND F 16.1:2:2.2:2.3.46-06, PND F 16.2.2:2.3:3.3402, Russian standard GOST 26485-85, PND F 16.1:2:2.2:3.65-10, Russian standard GOST 51802015.

The procedure PND F 16.1:2:2.2:2.3.4606 was applied for determination of weight portions of acid soluble forms of heavy metals and toxic elements: cadmium, copper, mercury, nickel, plumbum, zinc, cobalt, iron, manganese, arsenic, selenium, antimony, bismuth. Voltammetric method is based on analysis of current-voltage curves which show current of cell electrochemical reaction as a consequence of redox processes on electrode as a function of its polarization potential.

Calcium content was determine according to the procedure PND F 16.2.2:2.3:3.34-02. This method is based on generation of solid complex of Trilon B with calcium ions at $ð \mathbf{l}=12$, accompanied by variation of murexide coloring.

Aluminum content was determined according to Russian standard GOST 26485-85. The essence of the method is to extract exchange (mobile) aluminum form slag wastes by calcium chloride solution, obtaining of colored aluminum complex with chromazurol or xylenol orange in weak acid medium and subsequent photometric measurements of the color solution.

The procedure for determination of weight portion of silicon dioxide (PND F 16.1:2:2.2:3.65-10) is based on gravimetry. At the first stage a sample was fused with soda, at the second stage the fusion cake was leached and the metal salts were converted into chlorides by hydrochloric acid treatment. At the third stage silicic acid was extracted by gelatin. At the fourth stage silicic acid was oxidized to silicon dioxide with its determination by gravimetry.

Table 12: Quantitative chemical analysis of ash and slag mix from handling system prior to inclusion of cyclone

\begin{tabular}{|c|c|c|c|c|c|}
\hline \multirow{2}{*}{$\begin{array}{l}\text { Measured } \\
\text { properties }\end{array}$} & \multirow{2}{*}{$\begin{array}{l}\text { Units of } \\
\text { measurement }\end{array}$} & \multicolumn{3}{|c|}{ Results \pm error } & \multirow[t]{2}{*}{ Measurement procedures } \\
\hline & & $X_{1}$ & $X_{2}$ & $\mathbf{X}_{\text {mid }}$ & \\
\hline Cadmium & $\mathrm{mg} / \mathrm{kg}$ & $<0.1$ & $<0.1$ & $<0.1$ & PND F 16.1:2:2.2:2.3.46-06 \\
\hline Copper & $\mathrm{mg} / \mathrm{kg}$ & 33.9 & 34.9 & $34.4 \pm 8.6$ & \\
\hline Mercury & $\mathrm{mg} / \mathrm{kg}$ & $<0.1$ & $<0.1$ & $<0.1$ & \\
\hline Nickel & $\mathrm{mg} / \mathrm{kg}$ & $<0.5$ & $<0.5$ & $<0.5$ & \\
\hline Plumbum & $\mathrm{mg} / \mathrm{kg}$ & 18 & 16 & $17 \pm 4$ & \\
\hline Zinc & $\mathrm{mg} / \mathrm{kg}$ & $<1.0$ & $<1.0$ & $<1.0$ & \\
\hline Cobalt & $\mathrm{mg} / \mathrm{kg}$ & $<0.5$ & $<0.5$ & $<0.5$ & \\
\hline Iron & $\mathrm{mg} / \mathrm{kg}$ & 15987 & 17323 & $16655 \pm 4164$ & \\
\hline Manganese & $\mathrm{mg} / \mathrm{kg}$ & 1245 & 1031 & $1138 \pm 285$ & \\
\hline Arsenic & $\mathrm{mg} / \mathrm{kg}$ & $<0.1$ & $<0.1$ & $<0.1$ & \\
\hline Selenium & $\mathrm{mg} / \mathrm{kg}$ & $<0.1$ & $<0.1$ & $<0.1$ & \\
\hline Antimony & $\mathrm{mg} / \mathrm{kg}$ & $<1.0$ & $<1.0$ & $<1.0$ & \\
\hline Bismuth & $\mathrm{mg} / \mathrm{kg}$ & $<1.0$ & $<1.0$ & $<1.0$ & \\
\hline Calcium & $\mathrm{mg} / \mathrm{kg}$ & 141326 & 150103 & $145714 \pm 36429$ & PND F 16.2.2:2.3:3.34-02 \\
\hline Aluminum & $\mathrm{mg} / \mathrm{kg}$ & 60.3 & 64.6 & $62 \pm 16$ & $\begin{array}{l}\text { Russian standard GOST } \\
26485-85\end{array}$ \\
\hline Silicon dioxide & $\%$ & 58 & 58 & 58 & PND F 16.1:2:2.2:3.65-10 \\
\hline Moisture content & $\%$ & 1.3 & 1.3 & 1.3 & $\begin{array}{l}\text { Russian standard GOST } \\
5180-2015\end{array}$ \\
\hline
\end{tabular}


Moisture content of slag and ash wastes was determined according to Russian standard GOST $5180-2015$ by drying to steady weight.

The content of elements was converted into percentage on the basis of ratio of molecular weights of the compounds to relative atomic weight of elements.

\section{RESULTS}

Ash collecting facilities of Novocherkassk SDPP are equipped with two bag filters for capturing of particulate ash, aimed at high efficient cleaning of exhaust gases, which are not toxic, aggressive, fire and explosive dangerous, with the temperature not higher than $130-200^{\circ} \mathrm{C}$, these units operate in stationary gas flow. The gas flow is maintained by pneumatic pumps in order to override high pressure drop on filter. Group cyclone is used as the cleaning stage I aiming at reduction of dust emissions. This promoted reduction of dust load on the bag filters, which are the cleaning stage II. Cyclone design and analysis of operation of bag filters before and after cyclone implementation are discussed elsewhere ${ }^{12,13}$.

Properties of wastes (slag and ash mix) are summarized in Table 11. Description and code of wastes are given according to Federal Classificatory
Catalogue of Wastes (Decree of Ministry of natural resources and ecology of Russian Federation No. 445 dated July 18, 2014) and backgrounds for qualification of materials in terms of environmental hazard class.

In Russian industry the first cleaning stage is more frequently based on mechanical ash collectors operating on the principle of centrifuge forces, where deposition occurs upon flow rotation. Therefore, for preliminary coarse cleaning a TsN15-500 group cyclone (Scientific-Research Institute for Industrial Gases and Refuse Disposal design, Russia) was installed, comprised of four cyclone units with the diameter of $500 \mathrm{~mm}$. General view of the group cyclone is illustrated in Figure 1. Medium and coarse particles are deposited in cyclone under the action of centrifuge force.

An FRKI-90K-P3-2-2 bag filter is illustrated in Figure 2. The bag filter is equipped with pulse purge system for recovery of filtering material. Decrease in dust load would permit more efficient operation of filters due to application filtering surface for capturing of fine particles. Dust content before and after implementation of the cyclone demonstrated increase in efficiency of gas scrubbing system ${ }^{13}$.

Quantitative chemical analysis of slag and ash mix was determined according to approved in

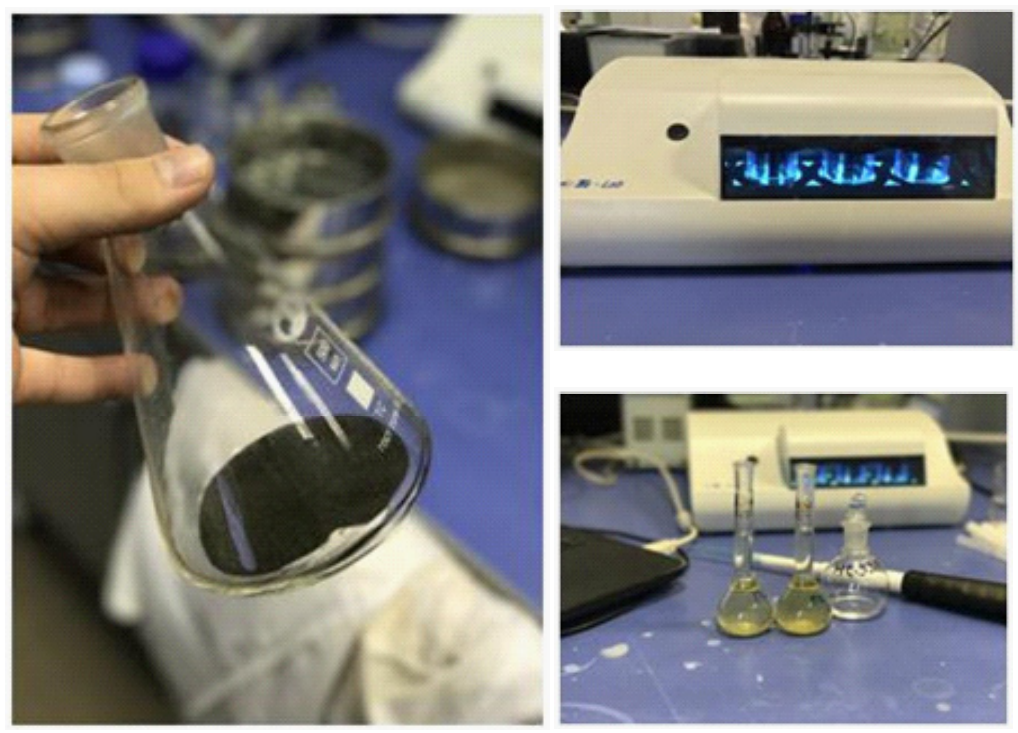

Fig. 4: Voltammetric analysis 
Russian Federation (RF) procedures: cadmium, copper, mercury, nickel, plumbum, zinc, cobalt, iron, manganese, arsenic, selenium, antimony, bismuth (PND F 16.1:2:2.2:2.3.46-06); calcium (PND F 16.2.2:2.3:3.34-02); aluminum (Russian standard GOST 26485-85); Silicon dioxide (PND F 16.1:2:2.2:3.65-10); Moisture content (Russian standard GOST 5180-2015) (Table 12-14).

It follows from Table 12 that the slag and ash mix of Novocherkassk SDPP contains significant amount of calcium -145714 mg/kg; iron -16655 mg/ $\mathrm{kg}$; manganese - $1138 \mathrm{mg} / \mathrm{kg}$; aluminum $-62.47 \mathrm{mg} /$ $\mathrm{kg}$; silicon dioxide $-58 \%$, and copper - $34.4 \mathrm{mg} / \mathrm{kg}$. Cadmium, mercury, arsenic, selenium, antimony, bismuth exist in trace amounts $<0,1 \mathrm{mg} / \mathrm{kg}$. The results in Tables 13 and 14 evidence that cadmium, copper, plumbum, zinc, iron, manganese and calcium are contained in coarse and fine particles captured by group cyclone and bag filter. Aluminum, a light metal, is nearly completely captured by cyclone $(57.3 \mathrm{mg} /$ $\mathrm{kg}$ ), since its content in the ash captured by filter is less than $5 \mathrm{mg} / \mathrm{kg}$.
On the basis of quantitative chemical analysis of the slag and ash mix (Table 12) the composition of wastes in Table 15 was determined. The environmental hazard class of the waste was determined by calculations according to the Decree of Ministry of natural resources and ecology of Russian Federation No. 536, dated December 04, 2014 titled On approval of criteria of waste classification as environmental hazard classes I-V. It follows form Table 15 that the total value of $\mathrm{K}_{i}$ is 96.904 , which is less than 100 , hence, the waste is referred hazard class IV.

Similarly, the hazard class of ash captured by group cyclone (Table 16) and that captured by bag filter (Table 17) were determined.

It follows from Tables 16 and 17 that total value $\mathrm{K}_{i}(65.966 ; 30.166)$ is less than 100 , hence, the waste is in hazard class IV.

\section{DISCUSSIONS}

It is established that slag and ash mix of Novocherkassk state district power plant after

Table 13: Quantitative chemical analysis of ash from group cyclone

\begin{tabular}{|c|c|c|c|c|c|}
\hline \multirow{2}{*}{$\begin{array}{l}\text { Measured } \\
\text { properties }\end{array}$} & \multirow{2}{*}{$\begin{array}{c}\text { Units of } \\
\text { measurement }\end{array}$} & \multicolumn{3}{|c|}{ Results \pm error } & \multirow[t]{2}{*}{ Measurement procedures } \\
\hline & & $x_{1}$ & $X_{2}$ & $\mathbf{X}_{\text {mid }}$ & \\
\hline Cadmium & $\mathrm{mg} / \mathrm{kg}$ & 0.40 & 0.45 & $0.43 \pm 0.11$ & PND F 16.1:2:2.2:2.3.46-06 \\
\hline Copper & $\mathrm{mg} / \mathrm{kg}$ & 70.9 & 81.6 & $76 \pm 19$ & \\
\hline Mercury & $\mathrm{mg} / \mathrm{kg}$ & $<0.1$ & $<0.1$ & $<0.1$ & \\
\hline Nickel & $\mathrm{mg} / \mathrm{kg}$ & $<0.5$ & $<0.5$ & $<0.5$ & \\
\hline Plumbum & $\mathrm{mg} / \mathrm{kg}$ & 16.0 & 15.5 & $16 \pm 4$ & \\
\hline Zinc & $\mathrm{mg} / \mathrm{kg}$ & 30.4 & 36.9 & $34 \pm 8$ & \\
\hline Cobalt & $\mathrm{mg} / \mathrm{kg}$ & $<0.5$ & $<0.5$ & $<0.5$ & \\
\hline Iron & $\mathrm{mg} / \mathrm{kg}$ & 14582 & 14896 & $14739 \pm 3685$ & \\
\hline Manganese & $\mathrm{mg} / \mathrm{kg}$ & 980 & 898 & $939 \pm 235$ & \\
\hline Arsenic & $\mathrm{mg} / \mathrm{kg}$ & $<0.1$ & $<0.1$ & $<0.1$ & \\
\hline Selenium & $\mathrm{mg} / \mathrm{kg}$ & $<0.1$ & $<0.1$ & $<0.1$ & \\
\hline Antimony & $\mathrm{mg} / \mathrm{kg}$ & $<1.0$ & $<1.0$ & $<1.0$ & \\
\hline Bismuth & $\mathrm{mg} / \mathrm{kg}$ & $<1.0$ & $<1.0$ & $<1.0$ & \\
\hline Calcium & $\mathrm{mg} / \mathrm{kg}$ & 98235 & 97364 & $97800 \pm 24500$ & PND F 16.2.2:2.3:3.34-02 \\
\hline Aluminum & $\mathrm{mg} / \mathrm{kg}$ & 58.2 & 56.4 & $57.3 \pm 14.3$ & $\begin{array}{l}\text { Russian standard GOST } \\
26485-85\end{array}$ \\
\hline Silicon dioxide & $\%$ & 74 & 73 & 74 & PND F 16.1:2:2.2:3.65-10 \\
\hline Moisture content & $\%$ & 1.0 & 1.0 & 1.0 & $\begin{array}{l}\text { Russian standard GOST } \\
5180-2015\end{array}$ \\
\hline
\end{tabular}


coal combustion has the following composition: iron $-2.3 \%$; mineral components $-75.8 \%$; calcium oxide $-20.4 \%$; aluminum oxide $-0.0118 \%$; water $1.3022 \%$; manganese oxide $-0.18 \%$; copper oxide
$-0.0043 \%$; plumbum $-0.0017 \%$, it is referred to environmental hazard class IV. Hazard class IV leads to noticeable biocenos depression and occurrence of irreversible violations of natural spheres.

Table 14: Quantitative chemical analysis of ash from bag filter (bunker bags)

\begin{tabular}{lccccc}
\hline $\begin{array}{l}\text { Measured } \\
\text { properties }\end{array}$ & $\begin{array}{c}\text { Units of } \\
\text { measurement }\end{array}$ & $\mathbf{X}_{1}$ & $\mathbf{X}_{2}$ & $\mathbf{X}_{\text {mid }}$ & Measurement procedures \\
\hline Cadmium & $\mathrm{mg} / \mathrm{kg}$ & 0.32 & 0.36 & $0.34 \pm 0.08$ & PND F 16.1:2:2.2:2.3.46-06 \\
Copper & $\mathrm{mg} / \mathrm{kg}$ & 42.8 & 37.8 & $40 \pm 12$ & \\
Mercury & $\mathrm{mg} / \mathrm{kg}$ & $<0.1$ & $<0.1$ & $<0.1$ & \\
Nickel & $\mathrm{mg} / \mathrm{kg}$ & $<0.5$ & $<0.5$ & $<0.5$ & \\
Plumbum & $\mathrm{mg} / \mathrm{kg}$ & 13.2 & 14.4 & $14 \pm 3$ & \\
Zinc & $\mathrm{mg} / \mathrm{kg}$ & 12.6 & 15.7 & $14 \pm 4$ & \\
Cobalt & $\mathrm{mg} / \mathrm{kg}$ & $<0.5$ & $<0.5$ & $<0.5$ & \\
Iron & $\mathrm{mg} / \mathrm{kg}$ & 1215 & 1132 & $1174 \pm 294$ & \\
Manganese & $\mathrm{mg} / \mathrm{kg}$ & 78 & 82 & $80 \pm 20$ & \\
Arsenic & $\mathrm{mg} / \mathrm{kg}$ & $<0.1$ & $<0.1$ & $<0.1$ & \\
Selenium & $\mathrm{mg} / \mathrm{kg}$ & $<0.1$ & $<0.1$ & $<0.1$ & \\
Antimony & $\mathrm{mg} / \mathrm{kg}$ & $<1.0$ & $<1.0$ & $<1.0$ & \\
Bismuth & $\mathrm{mg} / \mathrm{kg}$ & $<1.0$ & $<1.0$ & $<1.0$ & \\
Calcium & $\mathrm{mg} / \mathrm{kg}$ & 44398 & 43879 & $44139 \pm 11035$ & PND F 16.2.2:2.3:3.34-02 \\
Aluminum & $\mathrm{mg} / \mathrm{kg}$ & $<5$ & $<5$ & $<5$ & Russian standard GOST \\
Silicon dioxide & $\%$ & & & & $26485-85$ \\
Moisture content & $\%$ & 91 & 91 & 91 & PND F 16.1:2:2.2:3.65-10 \\
& & 0.4 & 0.4 & 0.4 & Russian standard GOST \\
& & & & & $5180-2015$ \\
& & & & &
\end{tabular}

Table 15: Composition of wastes (ash and slag mix)

\begin{tabular}{|c|c|c|c|}
\hline Components & $\begin{array}{l}\text { Concentration of the } \\
i \text {-th component in } \\
\text { wastes, } \mathrm{C}_{i}, \mathrm{mg} / \mathrm{kg}\end{array}$ & $\begin{array}{l}\text { Coefficient of hazard } \\
\text { level of the } i \text {-th component } \\
\text { of hazardous waste } \\
\text { for environment, } \mathrm{W}_{i}, \mathrm{mg} / \mathrm{kg}\end{array}$ & $\begin{array}{c}\mathrm{K}_{i}=\mathrm{C} / \mathrm{W}_{i} \text { - hazard level } \\
\text { of the } i \text {-th component of } \\
\text { hazard waste for } \\
\text { environment }\end{array}$ \\
\hline Calcium oxide & 204000.000 & 2154.43500 & 94.688 \\
\hline Water & 13022.000 & 1000000.00000 & 0.013 \\
\hline Mineral components & 758000.000 & 1000000.00000 & 0.758 \\
\hline Aluminum oxide & 118.000 & 6812.92100 & 0.017 \\
\hline Iron (II, III) oxides & 23000.000 & 37275.93700 & 0.617 \\
\hline $\begin{array}{l}\text { Manganese (in terms of } \\
\text { manganese (IV) oxide) }\end{array}$ & 1800.000 & 4641.58900 & 0.388 \\
\hline Lead and its compounds & 17.000 & 76.27000 & 0.223 \\
\hline Copper (II) oxide & 43.000 & 215.44300 & 0.200 \\
\hline Total: & 1000000.000 & & 96.904 \\
\hline
\end{tabular}


Analysis of ash color demonstrates that in total bulk the ash dust is of dark gray color. The ash captured by cyclone contains coarse particles of black color, and the ash captured by bag filter contains fine particles of light colors (gray-yellow color producing silky gloss). This is peculiar for ash dust after combustion of Donetsk culm. The main ash component of silicon dioxide, its content in the ash captured by filter reaches $91 \%$. These fine particles create light tone of this ash.

\section{CONCLUSIONS}

The issue of disposal and reprocessing of slag and ash wastes is a global challenge. Slag and ash dumps occupy high surface areas, they

Table 16: Composition of wastes (ash removed by group cyclone)

\begin{tabular}{|c|c|c|c|}
\hline Components & $\begin{array}{l}\text { Concentration of the } \\
i \text {-th component in } \\
\text { wastes, } C_{i j}, \mathrm{mg} / \mathrm{kg}\end{array}$ & $\begin{array}{l}\text { Coefficient of hazard level } \\
\text { of the } i \text {-th component of } \\
\text { hazardous waste for } \\
\text { environment, } \mathrm{W}_{i}, \mathrm{mg} / \mathrm{kg}\end{array}$ & $\begin{array}{c}\mathrm{K}_{i}=\mathrm{C} / \mathrm{W}_{i}-\text { hazard level } \\
\text { of the } i \text {-th component of } \\
\text { hazard waste for } \\
\text { environment }\end{array}$ \\
\hline Calcium oxide & 136920.000 & 2154.43500 & 63.553 \\
\hline Water & 10000.000 & 1000000.00000 & 0.010 \\
\hline Mineral components & 830987.570 & 1000000.00000 & 0.831 \\
\hline Aluminum oxide & 108.000 & 6812.92100 & 0.016 \\
\hline Iron (II, III) oxides & 20354.000 & 37275.93700 & 0.546 \\
\hline $\begin{array}{l}\text { Manganese (in terms of } \\
\text { manganese (IV) oxide) }\end{array}$ & 1485.000 & 4641.58900 & 0.320 \\
\hline Lead and its compounds & 16.000 & 76.27000 & 0.210 \\
\hline Copper (II) oxide & 95.000 & 215.44300 & 0.441 \\
\hline Zinc & 34.000 & 1467.79900 & 0.023 \\
\hline Cadmium & 0.430 & 26.90000 & 0.016 \\
\hline TOTAL: & 1000000.000 & - & 65.966 \\
\hline
\end{tabular}

Table 17: Composition of wastes (ash removed by bag filter)

\begin{tabular}{lccc}
\hline Components & $\begin{array}{c}\text { Concentration of the } \\
\boldsymbol{i} \text {-th component in } \\
\text { wastes, } \mathbf{C}_{\boldsymbol{i}} \mathbf{m g} \mathbf{\text { kg }}\end{array}$ & $\begin{array}{c}\text { Coefficient of hazard level } \\
\text { of the } \boldsymbol{i} \text {-th component of } \\
\text { hazardous waste for } \\
\text { environment, } \mathbf{W}_{\boldsymbol{i}}, \mathbf{m g} \mathbf{k g}\end{array}$ & $\begin{array}{c}\mathbf{K}_{\boldsymbol{i}}=\mathbf{C} / \mathbf{W}_{\boldsymbol{i}} \text { - hazard level of } \\
\text { the } \boldsymbol{i} \text {-th component of } \\
\text { hazard waste for } \\
\text { environment }\end{array}$ \\
\hline Calcium oxide & 61795.000 & 2154.43500 & 28.683 \\
Water & 4000.000 & 1000000.00000 & 0.004 \\
Mineral components & 929145.660 & 1000000.00000 & 0.929 \\
lron (II, III) oxides & 4864.000 & 37275.93700 & 0.130 \\
Manganese (in terms of & 127.000 & 4641.58900 & 0.027 \\
manganese (IV) oxide) & & & 0.184 \\
Lead and its compounds & 14.000 & 76.27000 & 0.186 \\
Copper (II) oxide & 40.000 & 215.44300 & 0.010 \\
Zinc & 14.000 & 1467.79900 & 0.013 \\
Cadmium & 0.340 & 26.90000 & 30.166 \\
TOTAL: & 1000000.000 & - & \\
\hline
\end{tabular}


are a source of pollution of environment, they are hazardous for human life, flora and fauna. Ash dumps are sources of accumulation of heavy metals (plumbum, copper, cadmium), they are characterized by increased radioactivity. Combustion products emitted into atmosphere result in acid rains and increase greenhouse effect, adversely effecting on total environmental situation.
The obtained experimental results evidence that ash and slag are valuable products, after their modification, for instance, by milling, they can be efficiently applied as additive for production of concrete, building materials, dry building mixes. This would permit to decrease cost of production of building materials and negative impact on environment. At present extraction technologies of calcium and iron are being developed.

\section{REFERENCES}

1. Chand P.; Kumar A.; Gaur A.; Mahna S.K. Elemental Analysis of Ash using X-Ray Fluorescence Technique. Asian Journal of Chemistry, 2009, 21(10), 220-224.

2. Bandlamudi D.; Avirneni S. Power Plant - A Scientific Disaster. International Journal of Engineering Research and Applications, 2013, 3(3), 061-065.

3. Liu H.; Sun Q.; Wang B.; Wang P and Zou J. Morphology and Composition of Microspheres in Fly Ash from the Luohuang Power Plant, Chongqing, Southwestern China. Minerals, 2016, 6, 30.

4. Rujoi B. G. Chemical composition of ash and slags obtained from lignite burning. U.P.B. Sci. Bull., Series B, 2010, 72(2), 15-22.

5. Karim M.R.; Zain M.F.M.; Jamil M.; Lai F.C. An experimental study on utilization of slag and fly ash as an alternative cementitious binder. Journal of Asian Scientific Research, 2012, 2(11), 620-625.

6. Malchik A.G.; Litovkin S.V.; Rodionov P.V. Reprocessing of slag wastes of thermal power plants upon production of building materials. Sovrem. Naukoemkie Tekhnologii, 2016, 3, 60-64.

7. Cherentsova A.A.; Maiorova L.P. On disposal of ash and slag wastes of thermal power plant (Khabarovsk TETs-3). TOGU Vestnik, 2013, 4(31), 101-106.

8. Andreeva N.G. Issued of disposal of ash and slag wastes of thermal power plant and approaches to their solution. Polzunov Vestnik, 2011, 4-2, 164-166.

9. Turchin V.V.; Yudina L.V.; Khamatova A.R.; et al. Sulfate corrosion of slag alkaline binders on the basis of fuel slag and ashes. Akt. Problemy Gumanit. Estest. Nauk, 2015, 3-1, 27-31. Date Views: 14.09.2016 http://publikacia.net/ archive/uploads/pages/2015_3_1/06.pdf

10. Yurev Iu.I.; Skripnikova N.A. Modified alumosilicate wastes for building ceramic materials. Pisma Material., 2013, 3, 268271.

11. Kapustin A.F.; Semerikov I.S. Composition and properties of composite cement with addition of ash and slag mix of thermal power plant. Vestnik YuUrGU, 2011, 16, 38-40.

12. Korotkova T.G.; Bushumov S.A. Design of $\mathrm{TsN}-15$ cyclone for pre-treatment of exhaust gases from ash and slag upon coal combustion in SDPP boilers. Scientific works KubSTU: Web magazine, 2016, 6: 73-82. Date Views: 10. 09.2016 http://ntk.kubstu. ru/file/1006

13. Korotkova T.G.; Bushumov S.A.; Danilchenko A.S.; et al. Reduction of dust emissions inclusion cyclone in ash capturing facility of Novocherkassk SDPP. Science Magazine Kuban State Agrarian University. Krasnodar: KubSAU, 2016, 06 (120). Date Views: 14.09.2016 http://ej.kubagro.ru/2016/06/ pdf/75.pdf. 